\title{
Very late stent thrombosis associated with COVID-19 infection: a case report and review of the literature
}

\author{
Shekhar Kunal'1, Vijay Pathak ${ }^{1}$, Keshav Pathak $^{2}$, Monika Mishra ${ }^{3}$, Shashi Mohan Sharma1, \\ Sudhir Bhandari ${ }^{2}$ \\ ${ }^{1}$ Department of Cardiology; ${ }^{2}$ Department of Medicine; ${ }^{3}$ Department of Pharmacology, Sawai Man Singh (SMS) Medical \\ College, Jaipur, Rajasthan, India
}

\begin{abstract}
Coronavirus disease 2019 (COVID-19), caused by SARSCoV-2 has varied manifestation with multisystem involvement. Acute coronary syndrome in COVID-19 as a result of stent thrombosis is an uncommon entity and is often due to hyperco-
\end{abstract}

Correspondence: Dr. Shekhar Kunal, Department of Cardiology, Sawai Man Singh (SMS) Medical College, Jaipur, Rajasthan, India. Mobile: +91.7678620444 .

E-mail: shekhar.kuna109@gmail.com

Key words: Acute coronary syndrome; coronavirus; COVID-19; pneumonia; stent thrombosis.

Contributions: SK, VP, SMS, contributed to the conception or design of the work; SK, VP, performed the procedure; SK, KP, MM, SB, contributed to the literature review; SK, VP, KP, SMS, MM, SB, drafted the manuscript; SK, VP, critically revised the manuscript. All the author gave final approval and agree to be accountable for all aspects of work ensuring integrity and accuracy.

Ethics approval and consent to participate: No ethical committee approval was required for this case report by the Department, because this article does not contain any studies with human participants or animals. Informed consent was obtained from the patient included in this study.

Consent for publication: A written informed consent was obtained from the patient regarding publication of the clinical details of the patient.

Conflict of interest: The authors declare that they have no competing interests, and all authors confirm accuracy.

Received for publication: 9 February 2021.

Accepted for publication: 11 August 2021.

COpyright: the Author(s), 2021

Licensee PAGEPress, Italy

Monaldi Archives for Chest Disease 2022; 92:1802

doi: 10.4081/monaldi.2021.1802

This article is distributed under the terms of the Creative Commons Attribution Noncommercial License (by-nc 4.0) which permits any noncommercial use, distribution, and reproduction in any medium, provided the original author(s) and source are credited. agulable state. A 40-year-old male was referred to us with acute onset chest pain. He also reported fever, sore throat and dry cough for six days which mandated testing for COVID-19 which turned out to be positive. He had a prior history of coronary artery disease with a drug eluting stent implanted two years back. An electrocardiogram was suggestive of acute anterior wall myocardial infarction while echocardiogram revealed hypokinesia of left anterior descending (LAD) artery territory. Coronary angiogram revealed non-occlusive thrombus in proximal LAD stent. A Thrombolysis in Myocardial Infarction (TIMI) III flow was restored following balloon angioplasty with a noncompliant balloon and use of glycoprotein (GP) IIb-IIIa receptor antagonist. A diagnosis of very late stent thrombosis subsequent to COVID-19 was made.

\section{Introduction}

COVID-19 caused by a novel coronavirus SARS-CoV-2 was first detected in Wuhan, China in 2019 and has since spread globally. It has resulted in a substantial increase in morbidity and mortality worldwide. As research into the pathophysiology and clinical manifestations of the disease has progressed, new insights have been gained into the systemic involvement of this novel coronavirus [1]. Cardiovascular manifestations in COVID-19 comprise acute coronary syndrome (ACS), myocarditis, pericarditis, pericardial effusion, heart failure and arrhythmias. ACS often results from a rupture/erosion of an atherosclerotic plaque leading to thrombus formation or stent thrombosis [1].

Stent thrombosis (ST) is a potentially catastrophic complication following coronary artery stenting leading to significant morbidity and mortality. As coronary intervention techniques have improved and with the use of novel dual anti-platelet therapy (DAPT), the incidence of stent thrombosis has decreased to less than a percent [2]. The Academic Research Consortium (ARC) [3] defines ST based on i) timing of ST (acute; sub-acute; late and very late), and ii) evidence of ST as definite "probable," or "possible". Very late stent thrombosis (VLST) refers to ST occurring beyond one year of stent implantation [3]. In this era of newer generation drug eluting stent (DES), VLST is an infrequent complication post percutaneous coronary intervention. It does, however, have life-threatening consequences resulting in acute MI or death, with mortality reported to be as high as $45 \%$ [4]. We present a middle-aged male with a prior history of coronary artery disease (CAD), who developed acute ST-segment elevation myocardial infarction (STEMI) due to VLST occurring two years after DES implantation following COVID-19 infection. 


\section{Case Report}

A 40-year-old non-smoker male was referred for complaints of sudden onset retrosternal chest pain for the past five hours which was radiating to his left arm along with profuse sweating and palpitations. He had a high-grade fever with chills, a sore throat, and a dry cough for the previous six days prior to this episode. He was initially treated at a COVID-19-designated hospital, where a chest radiograph revealed bilateral lower zone consolidation (Figure 1A). Furthermore, a positive reverse transcription polymerase chain reaction (RT-PCR) assay confirmed SARS-CoV-2 infection. For COVID-19 infection, he was administered tablet hydroxychloroquine and azithromycin along with supportive therapy. During the course of hospitalization, he developed acute onset chest pain and was referred to us with five hours having been elapsed between symptom onset and presentation in the Emergency Department. Since the patient was initially admitted in a COVID-19 designated hospital with limited resources to manage cardiovascular emergencies and complications, systemic fibrinolysis was not performed at that hospital and he was referred to a tertiary care cardiac center. On initial evaluation in the Emergency Department, the patient was hemodynamically stable, febrile with a pulse rate of 110/min, blood pressure of $110 / 70 \mathrm{mmHg}, \mathrm{SpO}_{2}$ of $95 \%$ while breathing ambient room air along with coarse crepitations in bilateral lower lung fields and a normal cardiovascular system examination. He had a prior history of CAD (non-STEMI) in the past and had undergone a DES implantation (sirolimus eluting: $3 \times 26 \mathrm{~mm}$ ) in the proximal left anterior descending (LAD) artery two years back. He had been on DAPT (tablet aspirin $75 \mathrm{mg}$ plus tablet clopidogrel $75 \mathrm{mg}$ once a day) with good compliance. There was no history of hypertension, diabetes, stroke or family history of CAD. Routine hematological tests were suggestive of lymphopenia with a normal total leucocyte count. Erythrocyte sedimentation rate (ESR), C-reactive protein (CRP) and D-dimer levels done previously on admission to the designated COVID-19 hospital for suspected SARS-CoV-2 infection were raised, suggestive of an inflammatory and prothrombotic state.
Electrocardiogram done on presentation in the Emergency Department was suggestive of ST-segment elevation in leads V1V6 (Figure 1B) while echocardiogram revealed hypokinesia of the anterior wall of left ventricle with trace mitral regurgitation and a left ventricular ejection fraction of $35 \%$. Patient was taken up for a coronary angiogram, following a written informed consent and a loading dose of aspirin $300 \mathrm{mg}$ and ticagrelor $180 \mathrm{mg}$ were administered. Coronary angiogram revealed the presence of a non-occlusive thrombus in the proximal LAD stent along with TIMI I flow (Figure 2; Videos 1 to 3 ). In addition, the ostium of the ramus intermedius too seemed to be diseased. Flow in LAD was restored following balloon angioplasty with a $3 \times 9 \mathrm{~mm}$ non-compliant balloon inflation at 16 atmospheres. In addition, a GP IIb-IIIa receptor antagonist (injection eptifibatide) was administered both as a bolus as well as an infusion in view of a large thrombus burden. Repeat angiogram revealed a TIMI III flow in the culprit vessel with markedly reduced thrombotic burden and mild in-stent restenosis (ISR) (Figure 3; Videos 4 and 5). A staged percutaneous coronary intervention (PCI) following fractional flow reserve (FFR) of the ramus intermedius lesion was planned. During the staged PCI procedure, a drug coated balloon (3 $\mathrm{mm}$ in diameter) was inflated for $60 \mathrm{~s}$ in the proximal LAD DES. The patient was continued on DAPT (tablet aspirin $75 \mathrm{mg}$ once a day and tablet ticagrelor $90 \mathrm{mg}$ twice daily) and discharged in a stable state following a negative RT-PCR for SARS-CoV-2. A diagnosis of a VLST secondary to COVID-19 infection resulting in an acute anterior wall myocardial infarction was made.

\section{Discussion}

VLST remains a rare but a serious complication following percutaneous coronary artery intervention. It continues to pose a significant therapeutic challenge despite markedly improved stent design and use of newer generation zotarolimus or everolimus eluting stents [4]. Major risk factors for VLST include diabetes, history of prior PCI, acute MI as an initial diagnosis, eGFR $<90$

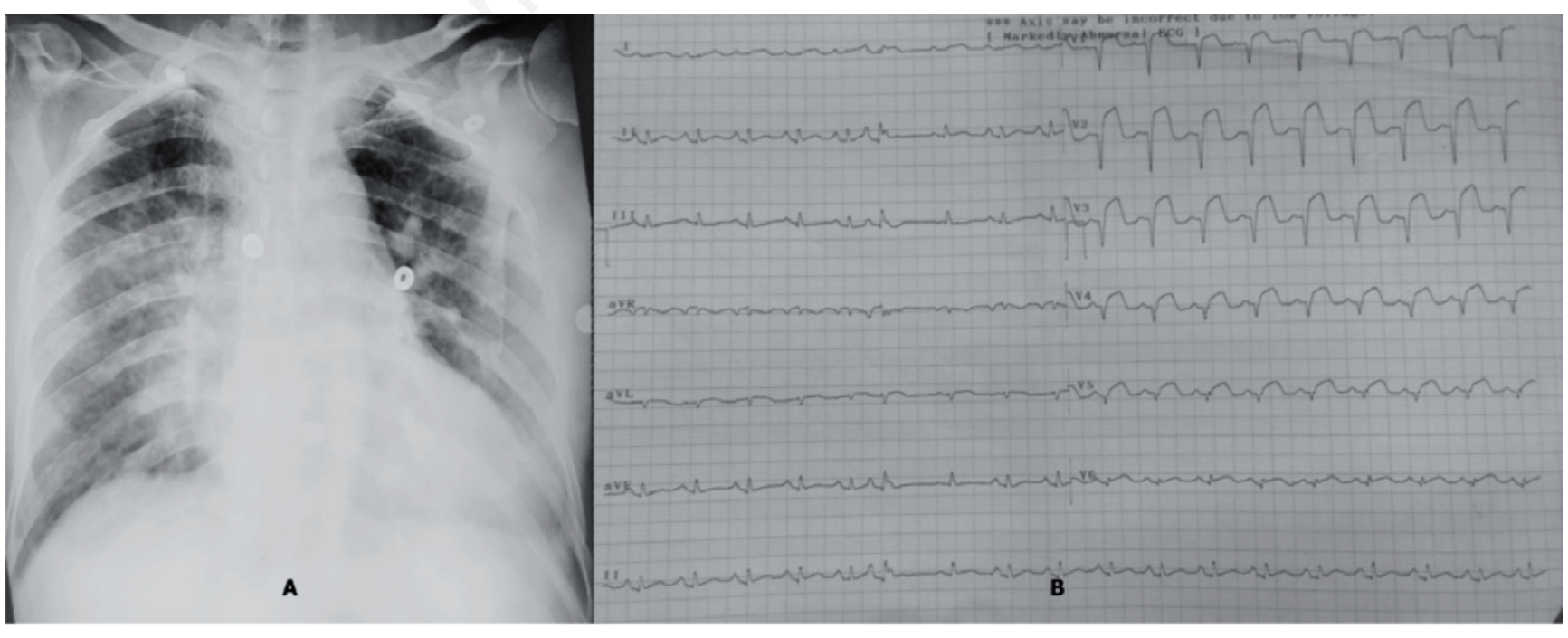

Figure 1. A) Chest radiograph postero-anterior view showing consolidation in bilateral mid and lower zones as well as in the right perihilar region suggestive of COVID-19 pneumonia. B) Twelve-lead electrocardiogram showing ST-segment elevation in leads V1-V6 suggestive of extensive anterior wall myocardial infarction. 
$\mathrm{ml} / \mathrm{min} / \mathrm{m}^{2}$, triple-vessel disease, greater number of stents implanted, first generation sirolimus eluting stent and lack of post-dilation. In addition, premature termination of antiplatelet therapy often increases the risk of VLST [5]. Previous reports have shown that the risk of VLST persists even until five years post DES implantation [4]. Predictors for late ST/VLST include younger patients, smokers, STEMI at time of initial DES implantation, number of diseased vessels, type $\mathrm{C}$ lesions, longer stent length and presence of overlapping stents [6]. The risk of VLST at the time of DES implantation can be estimated by a recently proposed "VLST scoring system". Based on this scoring system, our patient was categorized into low-risk for VLST (VLST score $<7$; predicted incidence: $<1 \%)$ [5].

Acute infections, especially respiratory tracts infections and systemic inflammation have been shown to facilitate the occurrence of ST often in individuals with a lower risk profile for ST [7]. "Acute infection-inflammation" leading to endothelial dysfunction and a systemic prothrombotic state has been considered to be the most plausible hypothesis for ST in these patients. This holds true even for COVID-19 infection which is characterized by a heightened systemic inflammatory response leading to an intense cytokine storm [1,8]. Furthermore, COVID-19 infection is also associated with a marked hypercoagulable state as evidenced by numerous reports of coronary thrombosis and venous thromboembolic events [9]. Systemic inflammation along with endothelial dysfunction and increased platelet activation often predisposes to acute thrombotic events in these patients. A higher thrombogenicity in COVID-19 infection has also been evident in patients presenting with ACS with greater thrombus burden and increased frequency of ST suggesting a pro-thrombotic state [10].

Although the exact mechanism causing ST in COVID-19 infection patients is unknown, it is frequently linked to increased platelet activation and endothelial dysfunction. In addition, there are speculations regarding the role of antiphospholipid antibodies in enhancing risk of thrombogenicity in these patients [11]. A

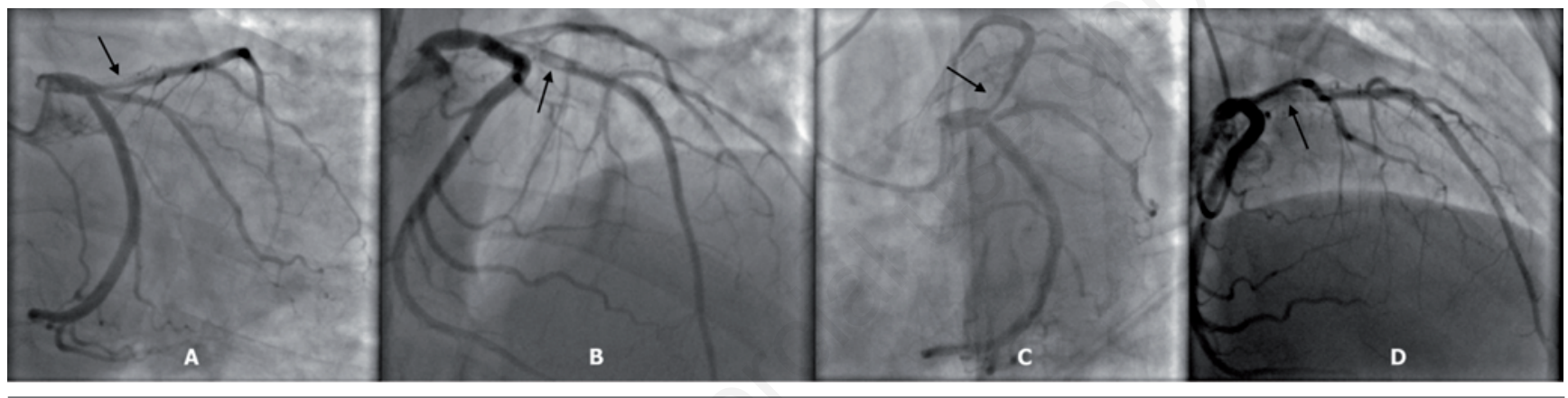

Figure 2. A) Left coronary artery (LCA) angiogram right anterior oblique (RAO) caudal view showing a filling defect (thrombus) within the stent deployed in the proximal segment of left anterior descending (LAD) artery (black arrow). B) LCA angiogram antero-posterior (AP) view showing a filling defect (thrombus) within the stent (black arrow) in the proximal segment of LAD. C) LCA angiogram left anterior oblique (LAO) caudal view showing a filling defect (thrombus) within the stent (black arrow) in the proximal segment of LAD. In addition, an ostial stenosis of ramus intermedius could be visualized. D) LCA angiogram RAO with slight cranial angulation showing a filling defect (thrombus) within the proximal LAD stent (black arrow).

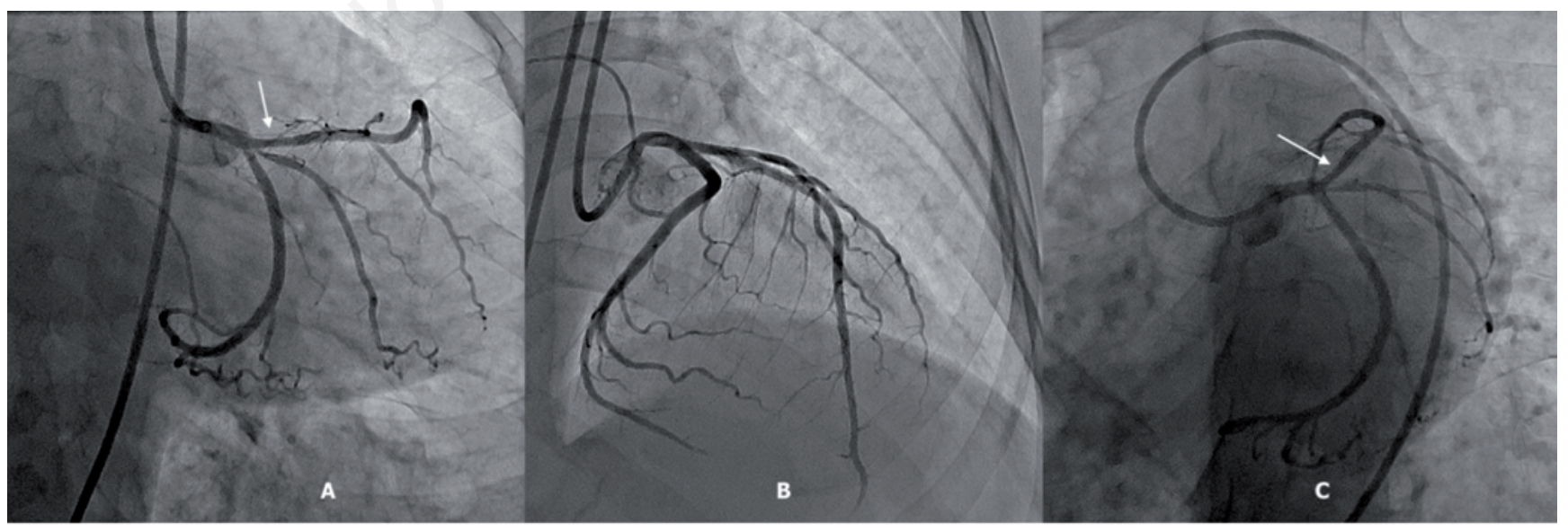

Figure 3. A) LCA angiogram RAO caudal view post balloon angioplasty showing resolution of thrombotic lesion in the proximal LAD stent with mild in-stent restenosis (white arrows). In addition, an ostial stenosis of ramus intermedius could be visualized. B) LCA angiogram AP view post balloon angioplasty showing resolution of thrombotic lesion in the proximal LAD stent. C) LCA angiogram LAO caudal view post balloon angioplasty showing resolution of thrombotic lesion in the proximal LAD stent with mild in-stent restenosis (white arrows). In addition, an ostial stenosis of ramus intermedius could be visualized. 
recent study among COVID-19 STEMI patients revealed an increased thrombotic burden as compared to those who were COVID-19 negative. This study further reported a higher frequency of multiple thrombotic culprit lesions, increased stent thrombosis with concomitant greater use of GP IIb/IIIa inhibitors and thrombus aspiration [10]. All these point towards a systemic hypercoagulable state in COVID-19. A low-risk profile for VLST (no prior risk factors for VLST) in our patient, combined with elevated D-dimer levels at presentation, emphasizes the role of a systemic hypercoagulable state triggered by COVID-19 infection in causing VLST. A review of the literature revealed a total of seven studies [11-17] comprising ten patients with COVID-19 infection and concomitant ST. All these patients were males and aged $>45$ years with VLST being the most common form of ST. Predisposition to ST apart from COVID-19 infection were present in six of the patients with duration of prior stent implantation ranging from 30 minutes to 13 years. Left anterior descending artery was the most commonly involved with thrombosuction used in $5 / 9$ patients and balloon angioplasty done in 8 of them. A majority of them survived with mortality reported in $3 / 10(30 \%)$ patients.
A limitation of this report could be a lack of an intracoronary imaging modality such as an IVUS or an OCT which could have shed more light on pathogenesis of VLST in our patient however, this was due to the resource limitation during the current pandemic and to shorten the procedure duration to prevent contagion to the medical staff. It is prudent to identify COVID-19 patients who are at a higher risk for ST and to use potent antiplatelet regimen in those patients. Two important implications which arise are the role of anti-inflammatory therapies and therapeutic anticoagulation in COVID-19 patients. In developing countries such as India, with an over increasing burden of COVID-19 cases, increasing lockdowns leading to delay in presentation to hospitals coupled by a poor healthcare infrastructure calls for a prompt identification and management of ACS including ST. A high index of suspicion for cardiovascular complications such as ACS and myocarditis should be kept in mind in patients with COVID19 infection presenting with chest pain and shortness of breath. There is a need for larger studies to highlight the exact pathophysiology of ST in COVID-19 infection and the role of therapies such as anti-viral medications, anti-inflammatory agents and thromboprophylaxis in mitigating the risk of ST.

Table 1. Review of cases of COVID-19 infection presenting with stent thrombosis.

\begin{tabular}{|c|c|c|c|c|c|c|c|c|c|c|c|}
\hline S No & $\begin{array}{l}\text { Authors, } \mathrm{Ni} \\
\text { Country of }\end{array}$ & $\begin{array}{l}\text { mber } \\
\text { atients }\end{array}$ & Age/Sex & $\begin{array}{l}\text { Risk } \\
\text { factors }\end{array}$ & $\begin{array}{c}\text { Stent } \\
\text { type, } \\
\text { implantation } \\
\text { duration }\end{array}$ & $\begin{array}{l}\text { Antiplatelet } \\
\text { use prior to } t \\
\text { presentation }\end{array}$ & $\begin{array}{l}\text { Stent } \\
\text { thrombosis } \\
\text { (acute, } \\
\text { sub-acute, } \\
\text { late, very } \\
\text { late) }\end{array}$ & $\begin{array}{l}\text { Culprit } \\
\text { artery }\end{array}$ & $\begin{array}{l}\text { Thrombus } \\
\text { aspiration/ } \\
\text { balloon } \\
\text { angioplasty/ } \\
\text { Stent/Gp } \\
\text { Ilb-IIla } \\
\text { inhibitor }\end{array}$ & $\begin{array}{l}\text { COVID-19 } \\
\text { status }\end{array}$ & Outcome \\
\hline 1. & $\begin{array}{l}\text { Antuna et al., } \\
\text { Spain [11] }\end{array}$ & 1 & 81/Male & $\begin{array}{l}\text { HTN } \\
\text { CAD }\end{array}$ & $\begin{array}{c}\text { DES, } \\
\text { Ridaforolimus, } \\
5 \text { years back } \\
\text { and } 3 \text { months } \\
\text { back }\end{array}$ & $\begin{array}{c}\text { Yes, DAPT } \\
\text { (aspirin + } \\
\text { clopidogrel) }\end{array}$ & Late ST & $\mathrm{LAD}$ & $\begin{array}{c}\text { Yes/ } \\
\text { Yes/No/No }\end{array}$ & $\begin{array}{l}\text { Symptomatic } \\
\text { (RT-PCR) }\end{array}$ & Survived \\
\hline 2. & $\begin{array}{l}\text { Hinterseer et al., } \\
\text { Germany [12] }\end{array}$ & 1 & 65/Male & $\begin{array}{l}\text { HTN, DM, } \\
\text { Dyslipidemia, } \\
\text { CAD } \\
\text { X }\end{array}$ & $\begin{array}{c}\text { DES } \\
\text { (Zotarolimus } \\
\text { X } 4 \text { years and } \\
\text { Everolimus } \\
\text { X } 2 \text { years back) }\end{array}$ & $\begin{array}{l}\text { Yes, single } \\
\text { antiplatelet } \\
\text { (aspirin } \\
100 \text { mg/day) }\end{array}$ & Very late ST & LAD & $\begin{array}{l}\text { Yes/Yes/ } \\
\text { Yes/No }\end{array}$ & $\begin{array}{l}\text { Symptomatic } \\
\text { (RT-PCR) }\end{array}$ & Died \\
\hline 3 & $\begin{array}{l}\text { Galeazzi et al., } \\
\text { Italy [13] }\end{array}$ & 1 & 79/Male & CAD & NA/2 years back & $\begin{array}{c}\text { Yes, single } \\
\text { antiplatelet } \\
\text { aspirin } 100 \mathrm{mg} / \text { day) }\end{array}$ & Very late ST & RCA & $\begin{array}{l}\text { NR/NR/ } \\
\text { NR/NR }\end{array}$ & $\begin{array}{l}\text { Symptomatic } \\
\text { (RT-PCR) }\end{array}$ & Died \\
\hline \multirow[t]{4}{*}{ 4. $\mathrm{P}$} & \multirow[t]{4}{*}{$\begin{array}{l}\text { Prieto-Lobato et al., } \\
\text { Spain [14] }\end{array}$} & \multirow[t]{4}{*}{4} & & & $\begin{array}{c}\mathrm{DES} / 30 \\
\text { minutes back }\end{array}$ & NR & Acute ST & LCX & \multirow{2}{*}{$\begin{array}{c}\text { No/Yes/No/ } \\
\text { Yes(Tirofiban) } \\
\text { Yes/Yes/ } \\
\text { Yes/Yes }\end{array}$} & $\begin{array}{l}\text { Symptomatic } \\
\text { (serology: IgG) }\end{array}$ & Survived \\
\hline & & & 71/Male & CAD, CKD & $\begin{array}{c}\text { BMS/13 years } \\
\text { back }\end{array}$ & NR & Very late ST & RCA & & $\begin{array}{l}\text { Symptomatic } \\
\text { (clinico- } \\
\text { radiological) }\end{array}$ & Survived \\
\hline & & & 86/Male & $\begin{array}{c}\text { CAD, CKD, } \\
\text { PAD }\end{array}$ & $\begin{array}{l}\text { DES/2 years } \\
\text { back }\end{array}$ & NR & Very late ST & $\mathrm{LAD}$ & $\begin{array}{l}\text { No/Yes } \\
\text { Nes/No }\end{array}$ & $\begin{array}{l}\text { Asymptomatic } \\
\text { (RT-PCR) }\end{array}$ & Survived \\
\hline & & & 85/Male & $\mathrm{CAD}$ & DES/4 years back & NR & Very late ST & $\mathrm{LAD}$ & $\begin{array}{c}\text { Yes/Yes/ A } \\
\text { No/Yes }\end{array}$ & $\begin{array}{l}\text { Asymptomatic } \\
\text { (serology: IgM) }\end{array}$ & Survived \\
\hline 5. & $\begin{array}{l}\text { Naderi et al., } \\
\text { Iran [15] }\end{array}$ & 1 & 61/Male & $\begin{array}{l}\text { HTN, } \\
\text { smoking, } \\
\text { CAD }\end{array}$ & $\begin{array}{c}\mathrm{DES} / 2 \\
\text { months back }\end{array}$ & NR & Late ST & $\mathrm{LAD}$ & $\begin{array}{l}\text { No/Yes/ } \\
\text { Yes/Yes }\end{array}$ & $\begin{array}{l}\text { Symptomatic } \\
\text { (RT-PCR) }\end{array}$ & Survived \\
\hline 6. & $\begin{array}{l}\text { Lacour et al., } \\
\text { France [17] }\end{array}$ & 1 & 68/Male & $\begin{array}{c}\text { DM } \\
\text { minutes back }\end{array}$ & $\mathrm{DES} / 120$ & $\begin{array}{c}\text { Yes, DAPT } \\
\text { aspirin+ticagrelor) }\end{array}$ & Acute ST & LAD & $\begin{array}{l}\text { Yes/Yes/ } \\
\text { No/No }\end{array}$ & $\begin{array}{l}\text { Symptomatic } \\
\text { (RT-PCR) }\end{array}$ & Died \\
\hline 7. & $\begin{array}{l}\text { Ayan et al., } \\
\text { USA [17] }\end{array}$ & 1 & 64/Male & $\begin{array}{c}\text { Chronic } \\
\text { hepatitis C, } \\
\text { HTN }\end{array}$ & $\begin{array}{l}\text { DES/72 hours } \\
\text { back }\end{array}$ & $\begin{array}{c}\text { Yes, DAPT } \\
\text { (aspirin + } \\
\text { clopidogrel) }\end{array}$ & Sub-acute ST & $\begin{array}{l}\text { Obtuse } \\
\text { marginal }\end{array}$ & $\begin{array}{l}\text { No/Yes/ } \\
\text { Yes/Yes }\end{array}$ & $\begin{array}{l}\text { Symptomatic } \\
\text { (RT-PCR) }\end{array}$ & Survived \\
\hline
\end{tabular}

BMS, bare metals stent; CAD, coronary artery disease; CKD, chronic kidney disease; DAPT, dual antiplatelet therapy; DES, drug eluting stent; DM, diabetes mellitus; HTN, hypertension; LAD, left anterior descending; LCX, left circumflex artery; NR, not reported; PAD, peripheral arterial disease; RC, right coronary artery; RT-PCR, reverse transcription polymerase chain reaction; ST, stent thrombosis; VLST, very late stent thrombosis. 


\section{VIDEO LEGENDS}

Video 1. LCA cine-angiogram RAO caudal view showing a filling defect (thrombus) within the stent deployed in the proximal segment of left anterior descending (LAD) artery.

Video 2. LCA cine-angiogram AP view showing a filling defect (thrombus) within the stent in the proximal segment of LAD.

Video 3. LCA angiogram LAO caudal view showing a filling defect (thrombus) within the stent in the proximal segment of LAD along with an ostial stenosis of ramus intermedius.

Video 4. LCA angiogram RAO caudal view post balloon angioplasty showing resolution of thrombotic lesion in the proximal LAD stent with mild in-stent restenosis.

Video 5. LCA angiogram LAO caudal view post balloon angioplasty showing resolution of thrombotic lesion in the proximal LAD stent with mild in-stent restenosis.

\section{References}

1. Kunal S, Gupta K, Sharma SM, et al. Cardiovascular system and COVID-19: perspectives from a developing country. Monaldi Arch Chest Dis 2020;90:1305.

2. Claessen BE, Henriques JP, Jaffer FA, et al. Stent thrombosis: a clinical perspective. JACC Cardiovasc Interv 2014;7:1081-92.

3. Cutlip DE, Nakazawa G, Krucoff MW, et al. Autopsy validation study of the academic research consortium stent thrombosis definition. JACC Cardiovasc Interv 2011;4:554-9.

4. Wang X, Chen X, Sun W, et al. Very late stent thrombosis in drug-eluting stents new observations and clinical implications. Cardiol Rev 2019;27:279-85.

5. Wang X, Chen X, Tian T, et al. A scoring system to predict the occurrence of very late stent thrombosis following percutaneous coronary intervention for acute coronary syndrome. Sci Rep 2020;10:6378.
6. Waksman R, Kirtane AJ, Torguson R, et al. Correlates and outcomes of late and very late drug-eluting stent thrombosis: results from DESERT (International Drug-Eluting Stent Event Registry of Thrombosis). JACC Cardiovasc Interv 2014; 7:1093-102.

7. Del Pace S, Boddi M, Rasoini R, et al. Acute infection-inflammation and coronary stent thrombosis: an observational study. Intern Emerg Med 2010;5:121-6.

8. Abou-Ismail MY, Diamond A, Kapoor S, et al. The hypercoagulable state in COVID-19: Incidence, pathophysiology, and management. Thromb Res 2020;194:101-15.

9. Kunal S, Bhatia H, Sharma SK, et al. Pulmonary thromboembolism in COVID-19: initial experience from India. J Clin Diagn Res 2020;14:OD05-OD07.

10. Choudry FA, Hamshere SM, Rathod KS, et al. High thrombus burden in patients with COVID-19 presenting with ST-elevation myocardial infarction. J Am Coll Cardiol 2020; 6:1168-76.

11. Antuña P, Rivero F, Del Val D, et al. Late coronary stent thrombosis in a patient with Coronavirus Disease 2019. JAMA Cardiol 2020;5:1195-8.

12. Hinterseer M, Zens M, Wimmer RJ, et al. Acute myocardial infarction due to coronary stent thrombosis in a symptomatic COVID-19 patient. Clin Res Cardiol 2021;110:302-6.

13. Galeazzi GL, Loffi M, Di Tano G, Danzi GB. Severe COVID19 pneumonia and very late stent thrombosis: a trigger or innocent bystander? Korean Circ J 2020;50:632-3.

14. Prieto-Lobato A, Ramos-Martínez R, Vallejo-Calcerrada N, et al. A case series of stent thrombosis during the COVID-19 pandemic. JACC Case Rep 2020;2:1291-6.

15. Naderi N, Ansari Ramandi MM, Baay M, et al. Cardiovascular patients in COVID-19 era, a case series, an experience from a tertiary cardiovascular center in Tehran, Iran. Clin Case Rep 2020;8:2436-42.

16. Lacour T, Semaan C, Genet T, Ivanes F. Insights for increased risk of failed fibrinolytic therapy and stent thrombosis associated with COVID-19 in ST-segment elevation myocardial infarction patients. Catheter Cardiovasc Interv 2021;97:E241-3.

17. Ayan M, Kovelamudi S, Al-Hawwas M. Subacute stent thrombosis in a patient with COVID-19 pneumonia. Proc (Bayl Univ Med Cent) 2020;34:175-7. 